\title{
Közleményeink iránti érdeklődés
}

\author{
Interest in our announcements
}

doi: 10.24365/ef.v59i4.363

Örömmel számolunk be arról, hogy az Egészségfejlesztés rendszeres olvasóinak köre folyamatosan bővül. Hónapok óta 7000 feletti a havi látogatóink száma. A lap „újraindulásakor” bíztunk benne, hogy az ingyenes, elektronikus megjelenésre való áttéréssel nem veszítjük el olvasóinkat, sőt, a fejlesztéssel inkább újakat szerzünk. Ez beigazolódott, 2016 januárja óta már csaknem megnégyszereződött a napi látogatószám.

$A z$ ősz végén megjelenik második, ezúttal „családi”" különszámunk, reméljük, hogy legalább akkora érdeklődés követi majd, mint az előző, márciusi különszámot.
A már jól ismert TOP 10-es listában az összefoglalók és teljes közlemények sorrendjét tekintve nem történt jelentős változás az előzőkhöz képest.

$A z$ „érdekességmutatóval” jellemzett - a megtekintések száma és a megjelenés óta eltelt napok száma hányadosa alapján mennyire bizonyul érdekesnek egy-egy cikk - már szerepelnek új közlemények is. Ilyen például a szerkesztőség által indított fikciós sorozat második része, az "Akció az irodában" írás - hasonlóan a "Képzelje el!" címü első részhez - ami a negyedik helyet foglalja el.

További látogatói és olvasottsági adatok találhatók az alábbi ábrán és táblázatban.

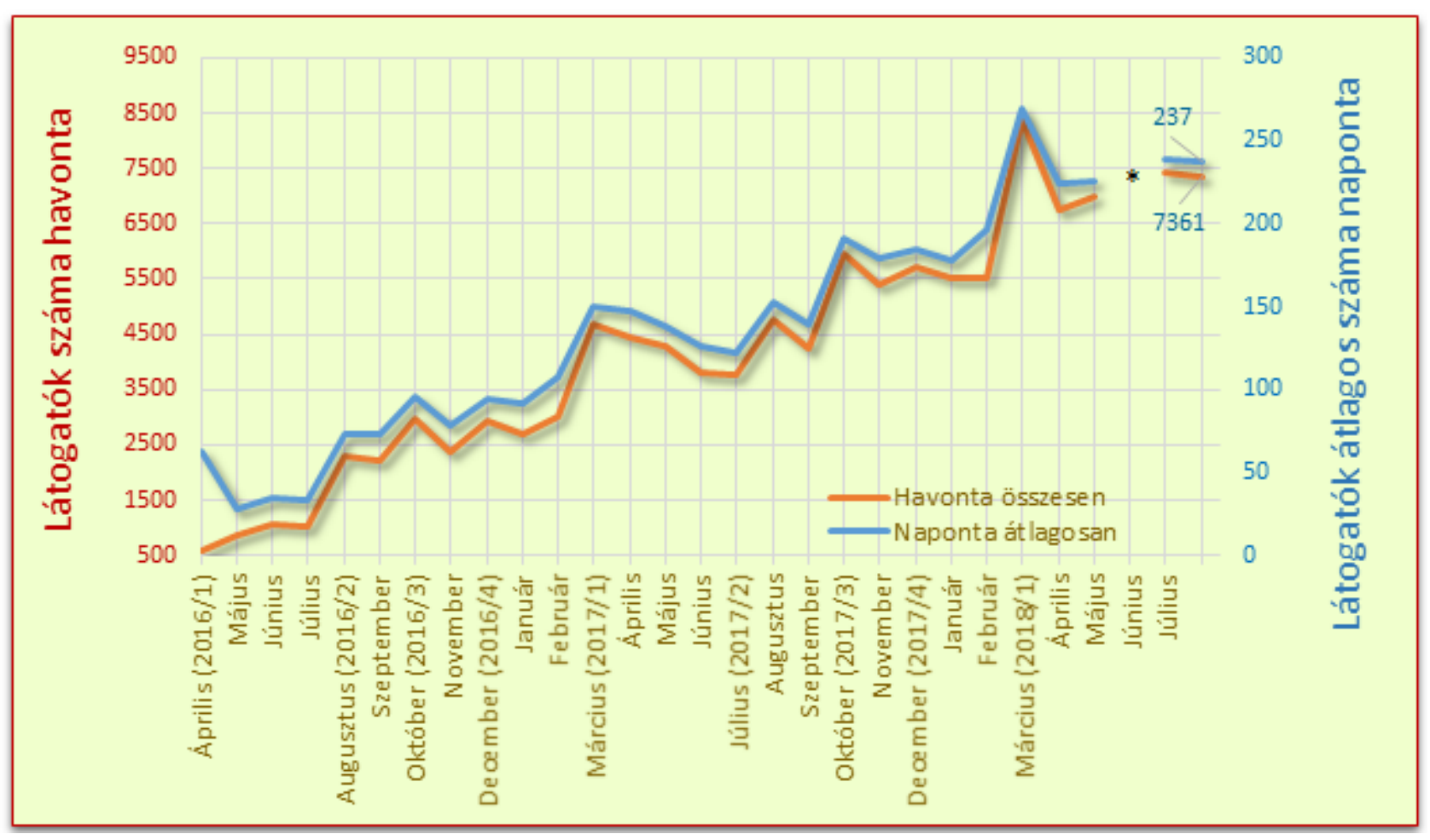

* nincs adat 


\begin{tabular}{|c|c|c|c|}
\hline $\begin{array}{c}\text { Megtekin- } \\
\text { tések } \\
\text { száma }\end{array}$ & Közlemény címe & Szerző́k & Lapszám \\
\hline \multicolumn{2}{|c|}{ ÖSSZEFOGLALÓ } & & \\
\hline 736 & Pályázati felhívás tudományos közlemény írására mesterképzéses hallgatóknak & szerkesztőség & 2018. 1. \\
\hline 598 & Egészséges életmóddal kapcsolatos kutatások a hazai iskolákban & Járomi É, Szilágyi K, Vitrai J & 2016. 1. \\
\hline 489 & $\begin{array}{l}\text { A 2015/2016. tanév országos fittségmérési eredményei a Nemzeti Egységes } \\
\text { Tanulói Fittségi Teszt (NETFIT®) alapján }\end{array}$ & Csányi T, Kaj M & 2017. 4. \\
\hline 480 & A kortársbántalmazás (bullying) mint népegészségügyi probléma & Várnai D, Zsíros E, Németh Á & 2016. 4. \\
\hline 448 & Hazai egészség-pillanatkép, 2017 & Vitrai J, Bakacs M, Varsányi P & 2017. 4. \\
\hline 432 & $\begin{array}{l}\text { A gyógytestnevelés jelentősége a szekunder rehabilitáció és egészségfejlesztés } \\
\text { folyamatában, megújulásának szükségessége, irányai }\end{array}$ & Simon I, Kajtár G & 2018. 1. \\
\hline 406 & $\begin{array}{l}\text { Egészpályás letámadás a kövérség ellen - Komplex beavatkozásokkal az elhízás } \\
\text { visszaszorítására }\end{array}$ & Vitrai J, Bakacs M & 2017. 4. \\
\hline 378 & $\begin{array}{l}\text { Magyarország népegészségügyi rendszere és egészségfejlesztéssel foglalkozó } \\
\text { szervezetei }\end{array}$ & Túri G et. Al & 2018. 2. \\
\hline 375 & Új hazai egészségmonitorozási koncepció & Varsányi P et al. & 2016. 1. \\
\hline 367 & Miért van szükségünk közösségalapú egészségfejlesztésre? & Benyó B & 2017. 4. \\
\hline \multicolumn{2}{|c|}{ TELES KÖZLEMÉNY } & & \\
\hline 2739 & A csecsemőkori allergiamegelőzés korszerú irányelvei és lehetőségei & Réthy A & 2017. 1. \\
\hline 887 & Egészségfejlesztési irodák hálózata & Bezzegh P & 2016. 1. \\
\hline 716 & Egészséges életmóddal kapcsolatos kutatások a hazai iskolákban & Járomi É, Szilágyi K, Vitrai J & 2016. 1. \\
\hline 483 & OKOSTÁNYÉR® - új táplálkozási ajánlás a hazai felnőtt lakosság számára & Szúcs Zs & 2016. 4. \\
\hline 370 & Hazai egészség-pillanatkép, 2017 & Vitrai J, Bakacs M, Varsányi P & 2017. 4. \\
\hline 336 & Az iskolai egészségfejlesztés hazai és nemzetközi szemléletének bemutatatása & Járomi É, Vitrai J & 2017. 1. \\
\hline 268 & $\begin{array}{l}\text { Magyarország népegészségügyi rendszere és egészségfejlesztéssel foglalkozó } \\
\text { szervezetei }\end{array}$ & Túri G et. Al & 2018. 2. \\
\hline 266 & $\begin{array}{l}\text { Összefoglaló „A munkahelyi egészzégfejlesztés általános szervezeti megvalósításá- } \\
\text { ra vonatkozó szakmai útmutató”-ról }\end{array}$ & Solymossy J, Koós T & 2016. 3. \\
\hline 258 & Amerikai táplálkozási ajánlás 2015-2020 - rövid ismertetés & Fekete $\mathrm{K}$, Henter I & 2016. 2. \\
\hline 247 & 2016-os éves jelentés a kábítószerhelyzetről - rövid összefoglaló & Nyírády A & 2016. 4. \\
\hline \multicolumn{2}{|c|}{ "ÉRDEKESSÉG" } & & \\
\hline 5,10 & A csecsemőkori allergiamegelőzés korszerú irányelvei és lehetőségei & Réthy A & 2017. 1. \\
\hline 2,15 & $\begin{array}{l}\text { Magyarország népegészségügyi rendszere és egészségfejlesztéssel foglalkozó } \\
\text { szervezetei }\end{array}$ & Túri G et al. & 2018. 2. \\
\hline 1,38 & Hazai egészség-pillanatkép, 2017 & Vitrai J, Bakacs M, Varsányi P & 2017. 4. \\
\hline 1,28 & Képzelje el! Akció az irodában & szerkesztőség & 2018. 3. \\
\hline 1,03 & Egészségfejlesztési Irodák hálózata & Bezzegh P & 2016. 1. \\
\hline 1,02 & $\begin{array}{l}\text { Kortárs egészségfejlesztési programok gyermekek és fiatalok körében a hazai és a } \\
\text { nemzetközi szakirodalom tükrében - Szisztematikus áttekintés }\end{array}$ & Lukács-Jakab Á et al. & 2018. 1. \\
\hline 1,02 & $\begin{array}{l}\text { A mintaadó népegészségügyi rendszerek elemzéséből levonható tanulságok és } \\
\text { következtetések }\end{array}$ & Túri G et al. & 2018. 2. \\
\hline 0,92 & Pályázati felhívás tudományos közlemény írására mesterképzéses hallgatóknak & szerkesztőség & 2018. 1. \\
\hline 0,83 & Egészséges életmóddal kapcsolatos kutatások a hazai iskolákban & Járomi É, Szilágyi K, Vitrai J & 2016. 1. \\
\hline 0,76 & OKOSTÁNYÉR ${ }^{\circledast}$ - új táplálkozási ajánlás a hazai felnőtt lakosság számára & Szúcs Zs & 2016. 4. \\
\hline
\end{tabular}

